\title{
Associations of Perception towards Doctors, Nurses, and Facilities with Perceived Quality and Patient Satisfaction on Inpatient Care at Nabire Hospital Papua
}

\author{
Agustina Utiii), Bhisma Murti' ${ }^{1)}$, Yulia Lanti Retno Dewi²) \\ 1)Masters Program in Public Health, Universitas Sebelas Maret \\ 2)Faculty of Medicine, Universitas Sebelas Maret
}

\section{ABSTRACT}

Background: The government's efforts to maintain and improve the highest health status with all resources in the health sector, including personnel, funds, facilities, pharmacy, medical devices, and technology, provide quality health care. Community satisfaction as the service receiver is a comparison between the services received and the services expected. This study aimed to examine associations of perception towards doctors, nurses, and facilities with perceived quality and patient satisfaction on inpatient care at Nabire Hospital Papua.

Subjects and Method: A cross-sectional study was conducted at Nabire Hospital, Papua, Indonesia, from March to May 2020. A sample of 207 inpatients was selected by stratified random sampling based on the type of inpatient class I, II, and III.

Results: Inpatient satisfaction was affected by age $<50$ years $(b=-0.36 ; 95 \% \mathrm{CI}=-1.63$ to 0.91; $\mathrm{p}=0.579$ ), type of non-BPJS insurance $(\mathrm{b}=0.19 ; 95 \% \mathrm{CI}=-0.80$ to $1.19 \mathrm{p}=0.697)$, length of stay $<7$ days $(b=-2.39 ; 95 \% \mathrm{CI}=-$ 3.86 to -0.92 ; $\mathrm{p}<0.001$ ), patients' perception towards adequate inpatient facilities $(b=3.11$; 95\% CI=2.13 to 4.07; $\mathrm{p}<0.001$ ), good quality of inpatient care $(b=2.74 ; 95 \% \mathrm{CI}=1.74$ to 3.72; $\mathrm{p}<0.001)$. The good quality of inpatient care was affected by male sex $(b=0.91 ; 95 \%$ $\mathrm{CI}=0.10$ to $1.72 ; \mathrm{p}=0.028$ ), age $<50$ years $(b=-0.24 ; 95 \% \mathrm{CI}=-1.26$ to $0.78 ; \mathrm{p}=0.644)$, type of BPJS insurance $(b=0.41 ; 95 \% \mathrm{CI}=-$ 1.22 to $0.39 ; \mathrm{p}=0.318$ ), perception towards adequate facilities $(b=1.85 ; 95 \% \mathrm{CI}=1.04$ to 2.65; p<0.001), good perception towards nurses $(b=2.18 ; 95 \% \mathrm{CI}=1.04$ to $3.33 ; \mathrm{p}$ $<0.001$ ), and good perception towards doctors $(\mathrm{b}=1.68 ; 95 \% \mathrm{CI}=0.89$ to $2.47 ; \mathrm{p}$ $<0.001)$. The good perception towards doctors was affected by the education of patients $\geq$ Senior High School $(b=1.16 ; 95 \% \mathrm{CI}=0.31$ to 1.83 ; $\mathrm{p}=0.005$ ).

Conclusion: Inpatient satisfaction is affected by age <50 years, type of non-BPJS insurance, length of stay $<7$ days, perception towards adequate facilities, and good quality of inpatient care.

Keywords: Quality, satisfaction, inpatient, path analysis

\section{Correspondence:}

Agustina Utii. Masters Program in Public Health, Universitas Sebelas Maret. Jl. Ir. Sutami 36A, Surakarta 57126, Central Java. Email: agustinautii1@gmail.com. Mobile: 081240051451.

\section{Cite this as:}

Utii A, Murti B, Dewi YLR (2020). Associations of Perception towards Doctors, Nurses, and Facilities with Perceived Quality and Patient Satisfaction on Inpatient Care at Nabire Hospital Papua. J Health Policy Manage. 05(03): 215-223. https://doi.org/10.26911/thejhpm.2020.05.03.07.

(c) (i) (2) Journal of Health Policy and Management is licensed under a Creative Commons (cc) Attribution-Non Commercial-Share Alike 4.0 International License.

\section{BACKGROUND}

Health is a human right. The health sector in the world is a pillar of the country that plays an important role in the progress of a country because it affects other sectors such as government, medical politics, social, moral, and business (Hussain et al., 2019). The hospital is one of the health care providers that the government provides. The health services that the community receives 
must be prime and complex. This service includes 4 aspects, such as promotive, preventive, curative, and rehabilitative (Wulandari, 2015). The phenomenon that often occurs when patients undergo inpatient care is disappointment and dissatisfaction with the quality of services provided by the hospital.

The result of the path analysis regarding the dissatisfaction felt by patients was affected by the patient's education level, family income, length of stay, income, and years of service of doctors, type of insurance, and type of class (Akbar et al., 2017).

A study conducted by Meesala and Paul (2018) concluded that showing friendly attitudes from employees, responsive concern, constraints, proper communication, accurate service delivery, on-time service affect patients satisfaction.

It also affects patient loyalty to the hospital. Based on the Nabire Hospital profile, the inpatients decreased in the last 3 years. It could occur due to various factors both internally and externally, such as the quality of care provided by the hospital. Nabire Hospital has a C accreditation status. It is the only public hospital that serves several regencies: Dogiyai, Paniai, Puncak, Puncak Jaya, Intan Jaya, Deiyai. Human resources in the health sector included 39 Doctors, 298 Nurses (69 interns, 98 contract employees, and 131 Civil Servants), 74 midwives (23 interns, 15 contract employees, 36 Civil Servants.

This study aimed to determine the effect of patient, type of insurance, type of class, patients' perceptions towards doctors and nurses on the quality of inpatient care satisfaction at Nabire Hospital, Papua.

\section{SUBJECTS AND METHOD}

\section{Study Design}

This study was an analytical observational study with a cross-sectional design. The study was conducted at Nabire Hospital, Papua, Indonesia, from March to May 2020.

\section{Population and Sample}

The target population in this study were all inpatients at Nabire Hospital, Papua. A sample of 207 inpatient was selected by stratified random sampling.

\section{Study Variables}

The dependent variable was quality and patient satisfaction. The independent variables were education, patient income, length of stay, type of inpatient class, service facilities, patients' perceptions towards nurses, doctors, service provider payment methods, care provider payment methods, and type of insurance.

\section{Operational Definition of Variables}

Education was the level of formal education that the patient took at a certain time and was proven by the last diploma.

Age was the length of time that a patient lived. This was stated in years according to information from the patient.

Type of Insurance was the participation of inpatients in financing health care.

Length of Stay was time taken by the patient during treatment, from the first day in units of days.

Perception towards facility was a patient's assessment of the facilities and infrastructure used during hospitalization.

Perception towards doctor was a patient's assessment of the attitudes and services provided by doctors during hospitalization.

Perception towards nurse was a patient's assessment of the attitude and services provided by nurses during hospitalization.

Quality of care was the patient's assessment of all health care at the hospital subjectively, according to the SERVQUAL method, namely tangible, reliability, responsiveness, assurance, empathy. 
Patient satisfaction was the patient's assessment of the services received during hospitalization as desired.

\section{Study Instruments}

The data were collected by a set of questionnaire.

\section{Data Analysis}

The data were analyzed univariately for the characteristics of inpatients. The data were analyzed bivariately with the Chi-square test. The data were analyzed by path analysis. Path analysis required model specifications, model identification, model suitability, parameter estimation, and model specifications.

\section{Research Ethic}

The code of ethics of the study, including informed consent, anonymity, and confi-

Table 1. The characteristics of the inpatients

\begin{tabular}{lcc}
\hline \multicolumn{1}{c}{ Variable } & n & Percentage (\%) \\
\hline Age & 29 & 14.99 \\
$\geq 5$ O years & 178 & 85.99 \\
<50 years & & 58.94 \\
Sex & 122 & 41.06 \\
Female & 85 & \\
Male & & 30.43 \\
Education & 63 & 69.57 \\
S Senior High School & 144 & 33.33 \\
S Senior High School & & 33.33 \\
Type of Inpatient classes & 69 & 33.33 \\
Class I & 69 & 31.88 \\
Class II & 69 & 68.12 \\
Class III & & \\
Patient Satisfaction & 66 & 32.37 \\
Not satisfied & 141 & 67.63 \\
Satisfied & & \\
Quality of Care & 67 & 33.98 \\
Poor & 140 & 66.02 \\
Patients' perceptions towards Doctors & & \\
Poor & 70 & 14.01 \\
Good & 136 & 85.99 \\
Patients' perceptions towards Nurses & & 29.95 \\
Poor & 29 & 70.05 \\
Good & 178 & \\
Patients' perceptions towards Facilities & 62 & \\
Inadequate & 145 & \\
Adequate & & \\
\hline
\end{tabular}

dentiality, was handled with care during the study process. The research ethics approval letter was obtained from the Research Ethics Committee of Dr. Moewardi Hospital, Surakarta, Indonesia, No. 216/II/HREC/2020, on February 17, 2020.

\section{RESULTS}

\section{Sample Characteristics}

Table 1 shows the data of patient characteristics. Based on the sex variable of the 207 study subjects, most of the subjects were female that were 122 study subjects (58, 94\%) and 85 study subjects were male (41.06\%). Inpatients education $\geq$ Senior High School were 144 people (69.57\%). The types of inpatient classes were divided into three classes. 
138 patients used non-BPJS insurance (66.67\%) and 69 people used national health insurance (33.33\%). 141 patients were satisfied (68.12\%). 140 people received good quality care (67.63\%). 136 people had good perception towards doctors (66.02\%). 178 people had good perception towards nurses (85.99\%). 145 people had perceptions of adequate health facilities (70.05\%).

\section{The result of bivariate analysis}

Table 2 shows the bivariate analysis using the Chi-square test on the effect of the inde- pendent and dependent variables. Male sex $(\mathrm{OR}=1.62 ; \mathrm{p}=0.122)$, age $<50$ years $(\mathrm{OR}=$ o.62; $\mathrm{p}=0.237)$, education $\geq$ Senior High School (OR= 1.22; $\mathrm{p}=0.535)$, and nonnational health insurance $(\mathrm{OR}=0.82 ; \mathrm{p}=$ 0.527). Length of stay $<7$ days $(\mathrm{OR}=0.26$; $\mathrm{p}=0.005$ ), patients' perceptions towards doctors ( $\mathrm{OR}=3.09 ; \mathrm{p}<0.001)$, patients' perceptions towards nurses $(O R=5.29 ; p$ $<0.001$ ), patients' perceptions towards facilities $(\mathrm{OR}=24.19 ; \mathrm{p}<0.001)$, and quality of care $(\mathrm{OR}=14.97 ; \mathrm{p}<0.001)$.

Table 2. The result of the bivariate analysis on inpatient satisfaction

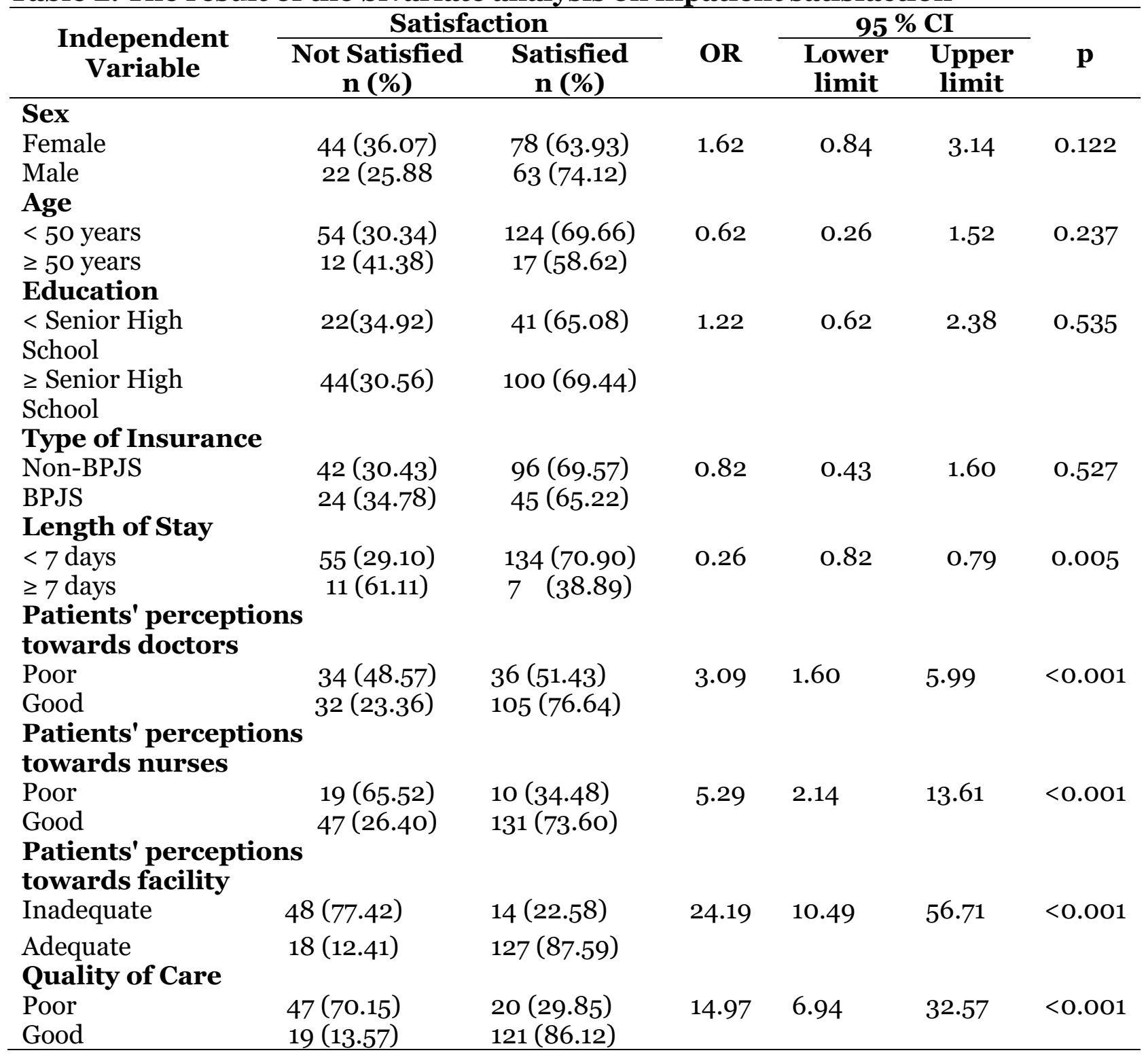




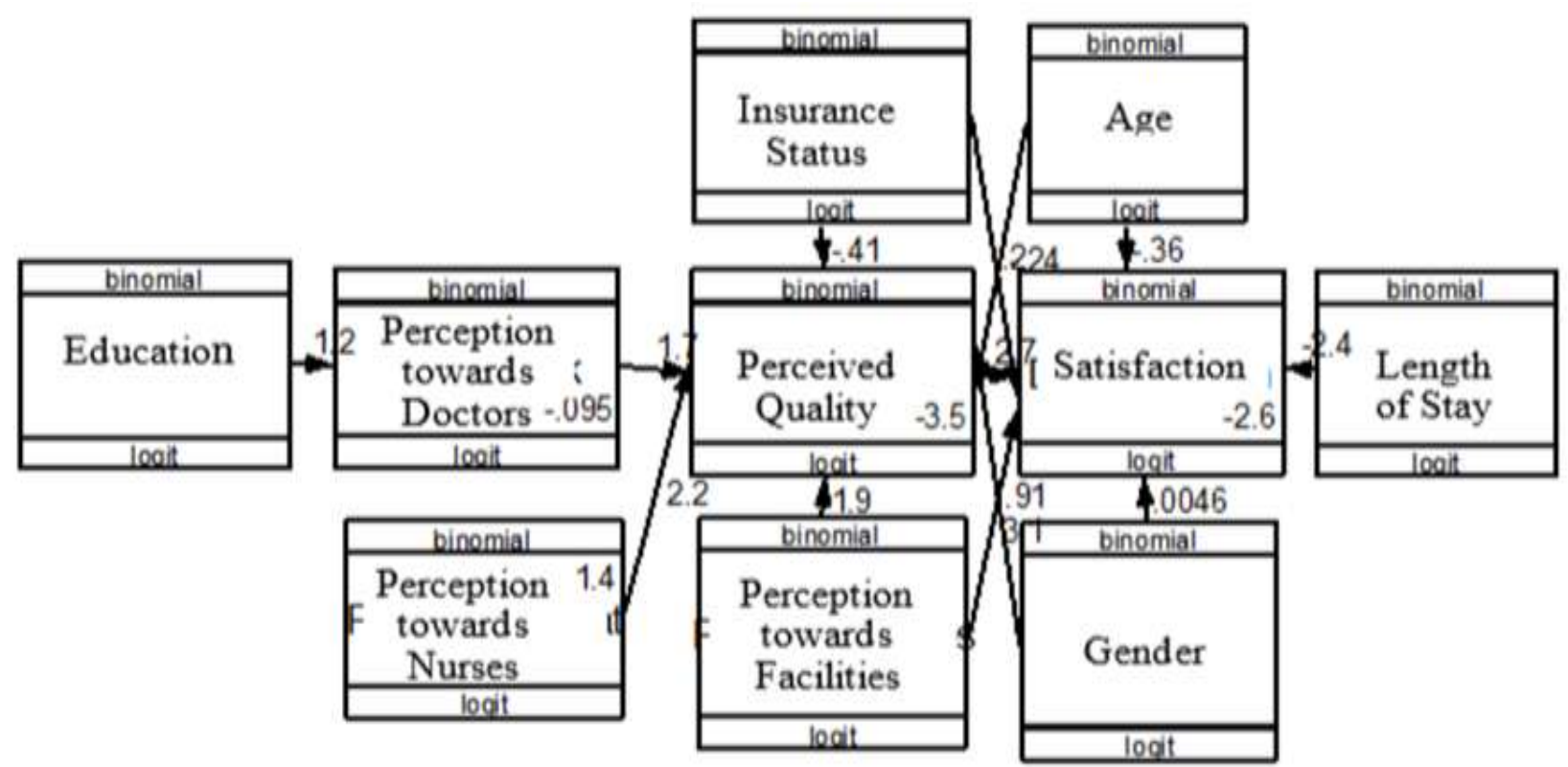

Figure 1. The path diagram of the factors affecting perceptions of health care quality and patient satisfaction

Table 3. The results of the path analysis of the factors affecting patients' perceptions on the quality and satisfaction of inpatient care at Nabire Hospital.

\begin{tabular}{|c|c|c|c|c|c|c|}
\hline \multirow[b]{2}{*}{$\begin{array}{c}\text { Dependent } \\
\text { Variable }\end{array}$} & & \multirow[b]{2}{*}{ Independent variable } & \multirow[b]{2}{*}{$\mathbf{b}$} & \multicolumn{2}{|c|}{$95 \%$ CI } & \multirow[b]{2}{*}{$\mathbf{p}$} \\
\hline & & & & $\begin{array}{l}\text { Lower } \\
\text { limit }\end{array}$ & $\begin{array}{l}\text { Upper } \\
\text { limit }\end{array}$ & \\
\hline \multicolumn{7}{|l|}{ Direct Effect } \\
\hline Satisfaction & $\leftarrow$ & Age (<50 years) & -0.36 & -1.63 & 0.91 & 0.579 \\
\hline Satisfaction & $\leftarrow$ & $\begin{array}{l}\text { Type of insurance } \\
\text { (Non BPJS) }\end{array}$ & 0.19 & -0.80 & 1.19 & 0.697 \\
\hline Satisfaction & $\leftarrow$ & $\begin{array}{l}\text { Length of stay } \\
\text { (<7 days })\end{array}$ & -2.39 & -3.86 & -0.92 & $<0.001$ \\
\hline Satisfaction & $\leftarrow$ & $\begin{array}{l}\text { Perception towards } \\
\text { facilities (Adequate) }\end{array}$ & 3.11 & 2.13 & 4.07 & $<0.001$ \\
\hline $\begin{array}{l}\text { Satisfaction } \\
\text { Indirect Effect }\end{array}$ & $\leftarrow$ & Quality (Good) & 2.74 & 1.74 & 3.72 & $<0.001$ \\
\hline Quality & $\leftarrow$ & $\begin{array}{l}\text { Sex } \\
\text { (Male) }\end{array}$ & 0.91 & 0.10 & 1.72 & 0.028 \\
\hline Quality & $\leftarrow$ & Age $(<50$ years $)$ & -0.24 & -1.26 & 0.78 & 0.644 \\
\hline Quality & $\leftarrow$ & $\begin{array}{l}\text { Type of insurance } \\
\text { (Non BPJS) }\end{array}$ & 0.41 & -1.22 & 0.39 & 0.318 \\
\hline Quality & $\leftarrow$ & $\begin{array}{l}\text { Perception towards } \\
\text { inpatient facilities } \\
\text { (Adequate) }\end{array}$ & 1.85 & 1.04 & 2.65 & $<0.001$ \\
\hline Quality & $\leftarrow$ & $\begin{array}{l}\text { Perception towards } \\
\text { Nurses (Good) }\end{array}$ & 2.18 & 1.04 & $3 \cdot 33$ & $<0.001$ \\
\hline Quality & $\leftarrow$ & $\begin{array}{l}\text { Perception towards } \\
\text { Doctors (Good) }\end{array}$ & 1.68 & 0.89 & 2.47 & $<0.001$ \\
\hline $\begin{array}{l}\text { Perception } \\
\text { towards Doctors } \\
\mathrm{N} \text { observation }=2 \\
\text { Likelihood }=-28\end{array}$ & $\begin{array}{l}7 \\
.93\end{array}$ & $\begin{array}{l}\text { Education } \\
\text { ( } \geq \text { Senior High School) }\end{array}$ & 1.16 & 0.31 & 1.83 & 0.005 \\
\hline
\end{tabular}




\section{The result of multivariate analysis}

Based on the results of the path analysis in Table 3, there was an effect of age on the satisfaction of inpatient care. Patients aged $<50$ years had 0.36 units lower log odds of being satisfied with inpatient care than inpatients aged $\geq 50$ years $(b=-0.36 \mathrm{CI} 95 \%=$ -1.63 to $0.91 ; \mathrm{p}=0.579$ ).

There was an effect of the type of insurance on inpatient satisfaction. Patients who used non-BPJS insurance had 0.19 units higher log odds to be satisfied with inpatient care than patients who used BPJS insurance $(b=$ -0.19 ; CI $95 \%=-0.80$ to $1.19 ; \mathrm{p}=0.697$ ). There was an effect of the type of insurance on inpatient satisfaction. Patients who used non-BPJS insurance had 0.19 units higher log odds to be satisfied with inpatient care than patients who used BPJS insurance $(b=$ - 0.19; CI 95\%= -0.80 to $1.19 ; \mathrm{p}=0.697$ ). There was an effect of length of stay on satisfaction. Patients treated $\geq 7$ days had 2.39 units lower log odds of being satisfied with inpatient care than patients treated $<7$ days $(b=-2.39$; CI 95\%= -3.86 to $-0.92 ; \leq$ o.001).

\section{DISCUSSION}

1. The effect of age on quality and satisfaction of inpatient care.

There was an effect of age on quality and patient satisfaction. Patients aged $<50$ years had a lower likelihood of being satisfied than inpatients aged $\geq 50$ years. Age affected satisfaction through good service quality. Inpatients aged $<50$ years had log odds of assessing the good quality. However, it was statistically non-significant.

Sulistyo (2019) stated that older patients with chronic diseases were more acceptable with decreased physical conditions. Patients also feel satisfied with health care faster than younger patients.

\section{The effect of type of insurance on quality and satisfaction of in- patient care.}

There was an effect of the type of insurance and non-BPJS on the quality and inpatients, but it was statistically non-significant.

Patients who used non-BPJS insurance had higher log odds of being satisfied with inpatient care than patients who used BPJS insurance.

Patient satisfaction increased through good service quality. In addition, patients with non-BPJS insurance had higher log odds of assessing the good quality of care than patients with BPJS insurance.

This study was not in line with a study conducted by Utami et al., (2017) that patients with BPJS health financing or insurance tend to assess the quality of service very well.

A literature review study by McMichael and Healy (2017) in Akbar (2017) concluded that there was no difference in the use of insurance in using quality health services and there was no difference in terms of equality of health services for both insurance users or independent or out of pocket in several countries in Southeast Asia (Cambodia, Laos, Myanmar, Thailand, Vietnam).

\section{The effect of length of stay on satis- faction of inpatient care.}

There was an effect of length of stay on patients who were treated for $<7$ days who had higher log odds of feeling satisfied than patients who were treated for $\geq 7$ days.

This study is in line with the path analysis study conducted by Sulistyo et al., (2019) that there was a direct and positive effect of length of stay on satisfaction. The result was statistically significant. Patients who was treated for $\geq 3$ days were 0.99 times more likely to be satisfied than $<3$ days. 


\section{The effect of perceptions towards inpatient facilities on the quality and satisfaction of inpatient care.}

There was an effect of patients' perception towards inpatient facilities on satisfaction.

Patients' perception towards adequate inpatient facilities were more likely to feel satisfied than patients who assessed that the facilities were inadequate.

In addition, there was an effect of inpatient facilities on patient satisfaction by assessing the good quality of inpatient care by the patients.

This is in line with a study conducted by Afriadi and Sihotang (2016) that facilities had a dominant effect on inpatient satisfaction with a relationship percentage value of $19.4 \%$.

\section{The effect of quality of inpatient care on patient satisfaction.}

There was an effect of the quality of inpatient care on patient satisfaction. Patients who assessed quality of inpatient care good had higher log odds to be satisfied with inpatient care than patients who assessed quality of inpatient care poor. It was statistically significant.

This study is in line with the results of the path analysis conducted by Akbar et al., (2017) which concluded that there was a direct and statistically significant effect between poor service quality and satisfaction.

\section{The effect of sex on the quality of inpatient care.}

There was an effect of sex on the quality of inpatient care. Male patients had better log odds of assessing the quality of inpatient care than female patients.

This is in line with the result of the path analysis conducted by Sulahyuningsi et al., (2017) that male patients had a direct and positive effect on inpatient satisfaction by 1.02 times compared to female patients. It was statistically significant.

\section{There was an effect of patients' perceptions towards nurses on the quality of inpatient care.}

There was an effect of patients' perceptions towards nurses on quality of care. Patients with good perceptions towards nurses had higher log odds of assessing the good quality of inpatient care than the poor perceptions towards nurses on the quality of inpatient care.

The quality of care that was considered good affected patient satisfaction. The fulfillment of patient needs would be able to provide an overview of patient satisfaction. Therefore, the level of patient satisfaction was very dependent on their perceptions or expectations of service providers (Bancin et al., 2018).

This study is in line with Saleh et al., (2018) that the services provided by medical personnel including friendly attitude, empathy, responsiveness, and reliability had a direct effect on patients' perceptions towards nurses.

\section{There was an effect of patients' perceptions towards doctors on the quality of inpatient care.}

There was an effect of patients' perceptions towards doctors on quality of care. Patients with good perceptions towards doctors had higher log odds of assessing the good quality of inpatient care than poor perceptions towards doctors on the quality of inpatient care.

Patients' perceptions regarding the quality of care provided by the health care system were affected by subjectivity. The patient's scientific and technical knowledge of medical care issues was very limited and the perceived quality of health care depended on the patient such as the patient's physical and psychological situation as well as the patient's characteristics and sociodemography (Mitropoulos et al., 2018) 
A study conducted by Satriyono and Kristanti (2018) concluded that the better the interaction between doctors and inpatients, the lower the patient's intention to discharge against medical advice (DAMA). Things that were considered to have an important role in building the patient's good perception towards doctors were the doctor's attitude, the doctor's expertise, and the doctor's behavior towards the patient.

\section{The effect of education on patients' perception towards doctors}

There was an effect of patient education on good perceptions towards doctors. Patients who had $\geq$ Senior High School education were more likely to give good quality on inpatient care than the patients who had $<$ Senior High School education. It was statistically.

According to Jacobalis (2000) in Listiani (2015), education level could affect a person's rational and irrational thinking in making decisions, using, or utilizing a health care. A person with low education had a high tendency of perceptual inconsistency (inconsistent), easily affected compared to someone with high educational background.

\section{AUTHOR CONTRIBUTION}

Agustina Utii was the main researcher who chose the topic, collected the data, formulated the articles, and processed the data. Bhisma Murti formulated the background and data analysis. Yulia Lanti Retno Dewi helped in formulating the framework and discussed it.

\section{CONFLICT OF INTEREST}

The authors declare there is no conflict of interest.

\section{FUNDING AND SPONSORSHIP}

This study used personal funds.

\section{ACKNOWLEDGEMENT}

The researchers would like to thank and appreciate the Nabire Hospital Papua and the respondents of the study who were willing to be the subjects of this study.

\section{REFERENCE}

Afriadi Y, Sihotang S (2016). Pengaruh kualitas layanan, harga, dan fasilitas terhadap kepuasan pasien rawat inap. JIRM, 5(6): 1-15.

Akbar SP (2017). Pengaruh faktor personal pasien, dokter, metode pembayaran dan tipe kelas bangsal terhadap kualitas dan kepuasan pelayanan rawat inap di RSUD Dr. Moewardi Surakarta, Tesis. Universitas Sebelas Maret.

Akbar SP, Adriani RB, Murti B (2017). The influence of personal factors of the patient, doctor, payment method and type of class to the quality and satisfaction of inpatient care services in Dr. Moewardi Hospital Surakarta. J Health Policy Manage. 02(01): 1-15. doi: 10.26911/thejhpm.2017.01.02.01.

Bancin ES, Aini F, Gunawan R (2018). Pengaruh faktor waktu pelayanan kenyamanan dan keistimewaan dan hubungan antar manusia terhadap kepuasan pasien pengguna BPJS di instalasi rawat inap RSUD Aceh Singkil. J Med Rec. 1(1): 41-52.

Hussain A, Sial MS, Usman SM, Hwang J, Jiang Y, Shafiq A (2019). What factors affect patient satisfaction in public sector hospitals: Evidence from an emerging economy. Int $J$ Environ Res Public Health. 16(6). https://doi. org/10.3390/ijerph1606.0994.

Listiani I (2015). Exploring the use and the impacts of social media on teaching and learning science in Saudi. Procedia Soc Behav Sci. 182: 213-224. 
McKinley SK, Wojci BM, Kochis M, Mansur A, Jones CB, Petrusa E, Phitayakorn R (2018). A pilot study of inpatient satisfaction rating of surgical resident care. J Surg Educ, 75(6): e192-e203. https://doi.org/10.1016/j.jsurg.2018.08.007.

Meesala A, Paul J (2018). Service quality, consumer satisfaction and loyalty in hospitals: Thinking for the future. J Retail Consum Serv. 40: -261-269. https://doi.org/10.1016/j.jretconser.2016.10.011.

Mitropoulos P, Vasileiou K, Mitropoulos I (2018). Understanding quality and satisfaction in public hospital services: A nationwide inpatient survey in Greece. J Retail Consum Serv. 40: 270-275. doi: 10.1016/j.jretconser.2017.03.004.

Oroh ME, Rompas S, Pondaag L (2014). Faktor-faktor yang berhubungan dengan tingkat kepuasan pasien rawat inap terhadap pelayanan keperawatan di ruang interna RSUD Noongan. Jurnal Keperawatan. Universitas Sam Ratulangi Manado.

Saleh M, Tamsah H, Feral EW (2018). Pengaruh ekspektasi, persepsi, kualitas pelayanan terhadap kepuasan pasien ruang rawat inap Rumah Sakit Bhayangkara Makassar. Jurnal Mirai Management, 3(1): o-15. https://journal.stieamkop.ac.id/index.php/mirai.
Satriyono G, Kristanti D (2018). Pengaruh kepuasan pasien pada kualitas layanan rawat inap terhadap niat discharge against medical advice (Dama) (Studi di Rumah Sakit Umum Daerah Pare Kabupaten Kediri). Ekonika: Jurnal ekonomi universitas kadiri, 3(2): 33 . doi: 10.30737/ekonika.v3i2.190.

Sulahyuningsih E, Tamtomo D, Joebagio H (2017). Analysis of patient safety management in committee for quality improvement and patient safety at Sumbawa Hospital, West Nusa Tenggara. J Health Policy Manage, 02(02): 147-156. doi: 10.26911/thejhpm.2017.02.02.0.

Sulistyo SA, Tamtomo D, Sulaeman ES (2018). Accreditation status and other factors affecting patient satisfaction in hospital. J Health Policy Manage. 139-149. doi: https://doi.org/10.26911/thejhpm.2019.04.03.01.

Sulistyo SA (2019). Pengaruh status akreditasi, kualitas pelayanan, sumber dana, lama perawatan, dan karakrteristik individu terhadap kepuasan pasien rawat inap di rumah sakit. Tesis. Universitas Sebelas Maret.

Utami YT, Tamtomo D, Sulaeman ES (2017). Patient characteristics, financing type, accreditation status, and quality of health services at community health center, Surakarta. J Health Policy Manage. 02(01): 79-90. doi: 10.26911/thejhpm.2017.01.02.07. 